\title{
Relationships between Cement Dust Emissions and Soil Properties
}

\author{
Serdar Bilen ${ }^{1 *}$, Murat Bilen², Veysel Turan ${ }^{3}$ \\ ${ }^{1}$ Ataturk University, Faculty of Agriculture, Department of Soil Science, Erzurum, Turkey \\ ${ }^{2}$ Eti Holding Research and Development Department, Guvercinlik, Ankara,Turkey \\ ${ }^{3}$ Bingol University, Faculty of Agriculture, Department of Soil Science, Bingol, Turkey
}

Received: 23 April 2018

Accepted: 22 June 2018

\begin{abstract}
Composite soils from conventional tillage (CT) and no-till (NT) fields under wheat (Triticum vulgare cultivar Dogu-88) were randomly collected (0-30 cm depth) in triplicate at 1, 5, 10, 15, 20 and $25 \mathrm{~km}$ distance to evaluate the effects of cement dust on soil basal respiration, microbial populations, enzyme activity and calculated soil quality (SQ) indices. Soil pH, exchangeable $\mathrm{Ca}$ and $\mathrm{Mg}, \mathrm{CaCO}_{3}$, and alkaline phosphatase (AlkP) showed a significant linear decrease in total organic C (TOC), total C (TC), urease activity (UA), and bacterial populations, and soil biological quality (SBQ) showed a significant linear increase with sampling distance from the cement plant. Total N (TN), available P (AP), basal respiration (BR), acid phosphate (AcdP) activity, dehydrogenase (DH) activity, fungal populations, and SQ showed a quadratic response with sampling distance. Soil $\mathrm{pH}, \mathrm{CaCO}_{3}$, TOC effective $\mathrm{CEC}, \mathrm{SBQ}$, soil chemical quality (SCQ), and SQ were significantly influenced by increasing distance.
\end{abstract}

Keywords: basal respiration, microbial population, soil enzymes, soil quality

\section{Introduction}

Industries that employ thermal processes all release airborne particles and gases into the surrounding environments. Unregulated industrial activities are often associated with environmental pollution $[1,2]$. Cement production is one type of industry that causes pollution particulate matter from various processes [3]. The main impacts of cement production on the environment are the broadcasts of dusts and gases $[1,4]$.

The cement dust discharged into the atmosphere from the cement plant are spread by wind and rain [4] and cement dust accumulating in soils can affect ecological

*e-mail: sbilen@atauni.edu.tr communities of soil systems. The most commonly used microbial activity indicators for soil health monitoring are microbial biomass, soil respiration and soil enzyme activity. Soil microbial activity is negatively affected by cement dust pollution [5, 6], and it is important for the nutrient biogeochemical cycling, nutrient recycling, processes of enzymatic functions and organic matter decomposition and, eventually, soil health $[1,7]$.

Cement dust induces changes in the physicochemical properties of soil that are generally unfavorable to plant growth [5]. Environmental pollution with cement dust by alkaline property affects all ingredients of the ecosystem [8]. Cement dust pollution generally causes alkalization of the ecosystem by changing electrical conductivity, 
$\mathrm{pH}$, and chemical composition of the soil [1,9]. Increasing soil $\mathrm{pH}$ values affects soil biological activities and enzyme activities that are highly related to soil moisture, temperature and $\mathrm{pH}[10,11]$.

Cement dust pollution may lead to a considerable decrease in microorganism population in soil and soil microbial biomass [12]. Enzymes are sensitive indicators showing microbial activity in soils [13]. Biological activity is a criterion to determine the effects of cultivation [14], field management [15] or soil contamination [16]. Soil biological activities are affected by soil tillage, crop rotation, and cover crops [17].

Islam and Weil [18], reported that no-till (NT) rejuvenates soil quality by increasing microbial diversity, improving energy-use efficiency, providing suitable habitats for microbes, and detoxifying contaminants. However, appropriate information is lacking regarding the effects of variable tillage systems on soil quality in response to alkaline dust emissions from cement plants.

\section{Material and Methods}

\section{Site Description}

The experimental study area is around Erzurum cement plant $\left(39^{\circ} 54^{\prime} \mathrm{N}\right.$ latitude and $41^{\circ} 13^{\prime} \mathrm{E}$ longitude at $1.880 \mathrm{~m}$ ) in eastern Turkey. Soil samples were collected from CT and NT fields $(0-30 \mathrm{~cm}$ depth) at distances of $1,5,10,15,20$, and $25 \mathrm{~km}$ away from the cement plant by considering wind direction of the cement plant and at each sampling site from three replicated plots (36 sampling sites). According to USDA soil taxonomy, study area soil series have been classified as ustorthents [19].

Soil fungi and bacteria were determined by the soil dilution plate method [20]. $1 \mathrm{~g}$ of soil sample was homogenized by diluting the series $\left(10^{1}-10^{5}\right)$ in $100 \mathrm{ml}$ phosphate-buffered saline solution $(0.15 \mathrm{M}$ potassium phosphate in $0.85 \% \mathrm{NaCl}, \mathrm{pH}$ 7.2) placed onto Petri dishes. Dilution of $10^{-5}$ was used to isolate bacteria and fungi. $1 \mathrm{ml}$ of microbial suspension was added to sterile Petri dishes (triplicate) containing about $15 \mathrm{ml}$ of sterile agar medium.

Soil extract agar was used for bacterial enumeration at $30^{\circ} \mathrm{C} \pm 2^{\circ} \mathrm{C}$ for 3 days, and potato dextrose agar (PDA) was used for fungal enumeration at $28 \pm 2^{\circ} \mathrm{C}$ for 3 days. Streptomycin solution (1\%) was added to the medium for preventing bacterial growth [21].

Average bacteria colony-forming units (cfu) per gram of oven-dried equivalent field-moist soil was calculated by an automated colony counter. Fungal colonies growing in agar were observed under dissecting microscope at 10-30×. Fungal colonies were observed under dissecting microscope at 10-30×. Total culturable fungi were calculated by viable fungal spore $\mathrm{g}^{-1}$ of ovendried soil [21].
Basal respiration (BR) was determined by using the sodium hydroxide $(\mathrm{NaOH})$ static incubation method [18]. According to this method, evolved $\mathrm{CO}_{2}$ was absorbed in the $0.5 \mathrm{M} \mathrm{NaOH}$ solution, incubated soil in the dark at $25 \pm 1^{\circ} \mathrm{C}$ for 20 days, and the $\mathrm{BR}$ rate $\left(\mathrm{mg} \mathrm{CO}_{2} \mathrm{~kg}^{-1}\right.$ soil d-1) of the soil was calculated by using BR $\left(\mathrm{mg} \mathrm{CO} \mathrm{kg}^{-1}\right.$ soil $\left.\mathrm{d}^{-1}\right)=\left(\mathrm{CO}_{2}\right.$ soil $-\mathrm{CO}_{2}$ air $) / 20 \mathrm{~d}$ formula.

Acid phosphatase (AcdP) and alkaline phosphatase (AlkP) enzyme activities were determined by using p-nitrophenyl phosphate (pNP) substrate (expressed as $\mu \mathrm{g} \mathrm{pNP} \mathrm{g^{-1 }}$ soil $^{-1}$ ). Urease activity (UA) was determined by using urea solution (expressed as $\mathrm{mg} \mathrm{NH}_{4}-\mathrm{N} \mathrm{kg}^{-1}$ soil $2 \mathrm{~h}^{-1}$ ). Soil dehydrogenase activity (DH) was determined through the reduction of triphenyl tetrazolium chloride (TTC) to triphenyl formazan (TPF) (expressed as mg TPF $\mathrm{kg}^{-1}$ soil $24 \mathrm{~h}^{-1}$ ), according to Tabatabai [22].

Soil organic matter (SOM) content was determined by the loss-on-ignition method, where a factor of 1.724 was used to convert SOM into total carbon (TC) content. [23], soil $\mathrm{CaCO}_{3}$ content by the pressure calcimeter method [24], soil total $\mathrm{N}$ content by the micro-Kjeldahl method, soil $\mathrm{pH}$ by the $\mathrm{pH}$ meter with the glass electrode meter in 1:2.5 soil:water ratio [25], exchangeable cations (EC) by Melich I solution $\left(0.125 \mathrm{M} \mathrm{H}_{2} \mathrm{SO}_{4}+0.5 \mathrm{M}\right.$ HCL), (EC) and cation exchange capacity (CEC) were calculated as the sum of the exchangeable cations determined by atomic absorption spectrophotometer [26], available P (AP) by the ammonium molybdateascorbic acid method, after extracting the soil with $0.5 \mathrm{M} \mathrm{Na}_{2} \mathrm{CO}_{3}$ [27], microelements by the diethylene triaminepentaacetic acid (DTPA) extraction method [28], soil particle size distribution by the hydrometer method [29], and soil textural class by the USDA textural triangle.

SQ was calculated according to the inductive additive approach average of selected biological and chemical properties into integrators of soil biology quality (SBQ) and soil chemical quality (SCQ). Soil biological or chemical property $\left(\mathrm{X}_{0}\right)$ datum calculated was transformed on a $[>0,<1]$ scale relative to the maximum value $\left(\mathrm{X}_{\max }\right)$ of that $\mathrm{X}_{0}$ in the dataset $\left(\mathrm{X}_{\mathrm{i}}=\mathrm{X}_{0} / \mathrm{X}_{\text {max }}\right) \cdot \mathrm{X}_{0}$ was performed to normalize the datasets for reducing heterogeneous variances of the errors and the relationship between random errors influenced variables. Equal weight was assigned to $X_{i}$ 's such that each $X_{i}$ was in $[>0,<1]$ scale and the mean SQ indices were calculated on a relative scale $[>0, \leq 1]$ by dividing with the total number of soil properties used (n). The SQ indices ranged from $>0$ to $\leq 1$, with 1 being excellent quality and $>0$ being poor SQ.

\section{Statistical Analysis}

All data were analyzed using analysis of variance procedure of the SAS Institute [30] in a factorial combination of 6 sampling distance $\times 2$ tillage systems. Functional dependence of sampling distance from cement dust on biological and chemical properties 
and SQ was analyzed using regression and correlation procedures.

\section{Results and Discussion}

\section{Soil Chemical Properties}

Some soil properties have changed by distance from cement plant. It has been observed that soil $\mathrm{pH}, \mathrm{CaCO}_{3}$, and $\mathrm{CN}$ ratio are higher at distances close to the cement plant and lower at far distances. Soil $\mathrm{pH}, \mathrm{CaCO}_{3}$, total organic $\mathrm{C}$ (TOC), and total $\mathrm{N}$ (TN) were significantly influenced by tillage and sampling distance interaction. The rate of decrease of soil $\mathrm{pH}$ was slightly lower in NT $\left(0.05\right.$ unit $\left.\mathrm{km}^{-1}\right)$ than in CT $\left(0.07\right.$ unit $\left.\mathrm{km}^{-1}\right)$. Likewise, the rate of $\mathrm{CaCO}_{3}$ decrease was lower in NT $\left(64 \mathrm{mg} \mathrm{kg}^{-1}\right.$ soil $\left.\mathrm{km}^{-1}\right)$ than in CT $\left(88 \mathrm{mg} \mathrm{kg}^{-1}\right.$ soil $\left.\mathrm{km}^{-1}\right)$. The rate of increase of total C (TC) was higher in NT (224 mg kg-1 soil $\left.\mathrm{km}^{-1}\right)$ than in CT $\left(200 \mathrm{mg} \mathrm{kg}^{-1}\right.$ soil $\left.\mathrm{km}^{-1}\right)$. Similarly, the rate increase of TOC was higher in NT $\left(220 \mathrm{mg} \mathrm{kg}^{-1}\right.$ soil $\left.\mathrm{km}^{-1}\right)$ than in CT $\left(124 \mathrm{mg} \mathrm{kg}{ }^{-1}\right.$ soil km-1). There is a decrease after 15 and $20 \mathrm{~km}$ in TC and TOC. These declines may be due to changing activities in cultivation and tillage. Cultivation can reduce SOC content and lead to soil deterioration, and finally reduce soil productivity [31].

In contrast, $\mathrm{TN}$ and $\mathrm{AP}$ showed a quadratic relationship with sampling distance. The $\mathrm{TN}$ increased at 56.0 and $64.0 \mathrm{mg} \mathrm{kg}^{-1}$ soil $\mathrm{km}^{-1}$ in $\mathrm{NT}$ and $\mathrm{CT}$, respectively. The AP increased at 180 and $250 \mathrm{mg} \mathrm{kg}^{-1}$ soil $\mathrm{km}^{-1}$ in the CT and NT, respectively (Table 1).

Table 1. Effects of cement dust on $\mathrm{pH}, \mathrm{TC}, \mathrm{CaO}_{3}, \mathrm{TOC}, \mathrm{TN}, \mathrm{C} / \mathrm{N}$ and $\mathrm{AP}$ in NT and $\mathrm{CT}$ soil at different sampling distances from the cement plant.

\begin{tabular}{|c|c|c|c|c|c|c|c|c|}
\hline \multirow{2}{*}{$\begin{array}{l}\text { Tillage } \\
\text { system }\end{array}$} & \multirow{2}{*}{$\begin{array}{l}\text { Sampling } \\
\text { distance }\end{array}$} & \multirow{2}{*}{$\begin{array}{c}\mathrm{pH} \\
(1: 2)\end{array}$} & TC & $\mathrm{CaCO}_{3}$ & TOC & $\mathrm{TN}$ & \multirow{2}{*}{$\begin{array}{l}\mathrm{C} / \mathrm{N} \\
\text { ratio }\end{array}$} & \multirow{2}{*}{$\begin{array}{c}\text { AP } \\
\mathrm{mg} \mathrm{kg}^{-1}\end{array}$} \\
\hline & & & \multicolumn{4}{|c|}{$\mathrm{g} \mathrm{kg}^{-1}$} & & \\
\hline & 1 & $8.6 b^{*}$ & $16.3 \mathrm{~d}$ & $5.8 \mathrm{a}$ & $10.7 \mathrm{~d}$ & $1.4 \mathrm{c}$ & $13.7 \mathrm{a}$ & $13.2 \mathrm{e}$ \\
\hline & 5 & $8.7 \mathrm{a}$ & $18.2 \mathrm{c}$ & $5.2 \mathrm{a}$ & $12.5 \mathrm{c}$ & $1.9 \mathrm{bc}$ & $12.2 b$ & $14.4 d$ \\
\hline & 10 & $8.2 \mathrm{c}$ & $19.8 b$ & $4.4 \mathrm{~b}$ & $12.6 \mathrm{c}$ & $2,1 \mathrm{bc}$ & $10.7 \mathrm{bc}$ & $16.4 \mathrm{bc}$ \\
\hline & 15 & $8.0 \mathrm{~d}$ & $21.7 \mathrm{a}$ & $4.0 \mathrm{c}$ & $16.9 \mathrm{a}$ & $2.4 \mathrm{~b}$ & $10.3 \mathrm{bc}$ & $15.9 \mathrm{c}$ \\
\hline & 20 & $7.8 \mathrm{~d}$ & $18.9 \mathrm{c}$ & $4.1 \mathrm{c}$ & $12.7 \mathrm{c}$ & $2.5 b$ & $9.9 \mathrm{c}$ & $16.8 \mathrm{~b}$ \\
\hline & 25 & $7.3 \mathrm{e}$ & $20.0 b$ & $3.9 \mathrm{c}$ & $14.3 b$ & $3,0 \mathrm{a}$ & $8.7 \mathrm{bc}$ & $18.6 \mathrm{a}$ \\
\hline & \multicolumn{8}{|c|}{ Tillage $\mathrm{x}$ sampling distance interaction } \\
\hline $\mathrm{CT}$ & 1 & 8.7 & 15.8 & 5.4 & 11.4 & 1.5 & 12.57 & 11.2 \\
\hline $\mathrm{CT}$ & 5 & 9.0 & 17.4 & 4.5 & 12.8 & 1.6 & 12.93 & 12.5 \\
\hline $\mathrm{CT}$ & 10 & 8.4 & 19.2 & 3.6 & 12.6 & 1.8 & 12.71 & 14.7 \\
\hline $\mathrm{CT}$ & 15 & 8.2 & 20.8 & 3.5 & 14.1 & 2.0 & 12.42 & 14.4 \\
\hline $\mathrm{CT}$ & 20 & 7.6 & 19.9 & 3.5 & 13.4 & 2.2 & 10.00 & 15.2 \\
\hline \multirow[t]{2}{*}{$\mathrm{CT}$} & 25 & 7.2 & 18.7 & 3.2 & 14.5 & 2.9 & 8.37 & 17.5 \\
\hline & Average & $8.1 X^{\dagger}$ & $18.6 \mathrm{Y}$ & $3.9 \mathrm{Y}$ & $13.1 \mathrm{X}$ & $2.0 \mathrm{Y}$ & $11.5 \mathrm{X}$ & $14.3 \mathrm{Y}$ \\
\hline NT & 1 & 8.5 & 17.0 & 6.4 & 11.7 & 1.3 & 14.93 & 15.2 \\
\hline NT & 5 & 8.3 & 19.0 & 5.8 & 13.8 & 2.1 & 11.47 & 16.3 \\
\hline NT & 10 & 8.0 & 20.4 & 5.2 & 14.1 & 2.4 & 10.82 & 18.2 \\
\hline NT & 15 & 7.7 & 22.6 & 4.8 & 17.2 & 2.8 & 10.31 & 17.5 \\
\hline NT & 20 & 7.9 & 18.9 & 4.9 & 13.7 & 2.6 & 8.84 & 18.5 \\
\hline \multirow[t]{2}{*}{ NT } & 25 & 7.2 & 22.3 & 5.0 & 15.7 & 2.9 & 9.38 & 19.7 \\
\hline & Average & $7.9 X$ & $20.0 X$ & $5.3 \mathrm{X}$ & $14.3 X$ & $2.3 \mathrm{X}$ & $10.9 \mathrm{X}$ & $17.5 X$ \\
\hline \multicolumn{2}{|c|}{$\begin{array}{l}\mathrm{LSD}_{\mathrm{P} \leq 0.05} \\
\text { Tillage } \mathrm{x} \text { distance }\end{array}$} & 0.2 & ns & 0.2 & 0.1 & 0.18 & ns & ns \\
\hline
\end{tabular}

$\mathrm{CT}=$ Conventional-till, $\mathrm{NT}=$ No-till, $\mathrm{TC}=$ Total carbon, $\mathrm{CaCO}_{3}=$ Calcium carbonate, $\mathrm{TC}=$ Total carbon, $\mathrm{TOC}=$ Total organic carbon, $\mathrm{TN}=$ Total nitrogen, and $\mathrm{AP}=$ Available phosphorus.

$\dagger$ Mean separated by same upper case letter between CT and NT within each column was non-significant at $p \leq 0.05$ by tillage.

* Mean separated by upper case letter within each column was non-significant at $\mathrm{p} \leq 0.05$ by sampling distance. 
Tillage and sampling distance had a significant interaction on $\mathrm{Na}, \mathrm{Cu}, \mathrm{Zn}, \mathrm{Mn}$, and effective cation exchange capacity (ECEC). The rate of decrease of $\mathrm{Ca}$ was higher in CT (56 mg kg-1 soil km${ }^{-1}$ ) than in NT (52 mg kg-1 soil km $\mathrm{km}^{-1}$ ), and the rate of decrease of $\mathrm{Mg}$ was higher in CT $\left(20 \mathrm{mg} \mathrm{kg}^{-1}\right.$ soil km $\left.\mathrm{km}^{-1}\right)$ than in NT (12 $\mathrm{mg} \mathrm{kg}^{-1}$ soil km${ }^{-1}$ ). Although Ca content was higher in NT than in CT, it did not vary consistently between CT and NT. Moreover, NT had $6.66 \%$ higher K than CT. In contrast, $\mathrm{Cu}, \mathrm{Zn}$, and $\mathrm{Mn}$ contents increased with increased sampling distance. Although the ECEC did not vary by tillage, it varied significantly by sampling distance and showed a significant linear decrease under NT and non-linear decrease under CT (Table 2; Fig. 1).

Since the $\mathrm{pH}$ of the unpolluted soil is neutral in reaction, a significantly higher $\mathrm{pH}$ with decreasing sampling distance in both CT and NT is most probably associated with greater deposition of $\mathrm{CaCO}_{3}-\mathrm{Ca}$ - and Mg-enriched dust emitted from the cement plant [32]. A significant non-linear increase of soil $\mathrm{pH}\left(\mathrm{r}^{2}=0.41\right)$ in response to corresponding $\mathrm{Ca}$ and $\mathrm{Mg}$ content justifies our explanation (Fig. 2).

Moreover, a higher soil $\mathrm{pH}$ is often associated with the effects of higher CEC and base saturation. A significant positive correlation of $\mathrm{Cu}$ and $\mathrm{Mn}$ with sampling distance is possibly due to less solubility of the metals in high $\mathrm{pH}$ soil near the cement plant. Extractable microelements have shown regular change up to $15 \mathrm{~km}$ sampling distance. After $15 \mathrm{~km}$ sampling distance, especially iron and manganese, have shown irregular change. Several studies have reported that the availability of $\mathrm{Mn}, \mathrm{Fe}, \mathrm{Cu}$ and $\mathrm{Zn}$ are tending to decrease depending on soil $\mathrm{pH}$ increases [33, 34].

Table 2. Effects of cement dust on extractable $\mathrm{Ca}, \mathrm{Mg}, \mathrm{K}, \mathrm{Na}, \mathrm{Fe}, \mathrm{Cu}, \mathrm{Zn}$ and $\mathrm{Mn}$ in NT and $\mathrm{CT}$ soil at different sampling distances from the cement plant.

\begin{tabular}{|c|c|c|c|c|c|c|c|c|c|}
\hline \multirow{3}{*}{$\begin{array}{l}\text { Tillage } \\
\text { system }\end{array}$} & \multirow{2}{*}{$\begin{array}{l}\text { Sampling } \\
\text { distance }\end{array}$} & $\mathrm{Ca}$ & $\mathrm{Mg}$ & $\mathrm{K}$ & $\mathrm{Na}$ & $\mathrm{Fe}$ & $\mathrm{Cu}$ & $\mathrm{Zn}$ & $\mathrm{Mn}$ \\
\hline & & \multicolumn{4}{|c|}{$\mathrm{g} \mathrm{kg}^{-1}$} & \multicolumn{4}{|c|}{$\mathrm{mg} \mathrm{kg}^{-1}$} \\
\hline & 1 & $5.0 \mathrm{a}^{*}$ & $1.5 \mathrm{a}$ & $1.7 \mathrm{~b}$ & $81.3 b$ & $27.6 \mathrm{a}$ & $3.4 \mathrm{c}$ & $2.9 \mathrm{a}$ & $11.5 \mathrm{c}$ \\
\hline & 5 & $4.9 \mathrm{a}$ & $1.3 \mathrm{ab}$ & $1.5 \mathrm{bc}$ & $74.5 b$ & $23.5 b$ & $3.7 \mathrm{c}$ & $2.1 b$ & $12.6 \mathrm{~b}$ \\
\hline & 10 & $4.7 \mathrm{a}$ & $1.2 \mathrm{ab}$ & $1.2 \mathrm{~d}$ & $68.4 b$ & $27.8 \mathrm{a}$ & $3.3 \mathrm{c}$ & $1.6 \mathrm{~b}$ & $13.6 \mathrm{~b}$ \\
\hline & 15 & $4.2 \mathrm{ab}$ & $1.2 \mathrm{~b}$ & $1.3 \mathrm{~cd}$ & $69.1 b$ & $23.4 \mathrm{a}$ & $3.9 \mathrm{c}$ & $1.8 \mathrm{~b}$ & $11.9 \mathrm{c}$ \\
\hline & 20 & $4.4 \mathrm{ab}$ & $1.2 \mathrm{~b}$ & $1.4 \mathrm{c}$ & $98.4 \mathrm{a}$ & $26.1 \mathrm{ab}$ & $5.1 \mathrm{a}$ & $2.4 \mathrm{a}$ & $13.7 \mathrm{~b}$ \\
\hline & 25 & $3.6 \mathrm{~b}$ & $1.0 \mathrm{c}$ & $1.9 \mathrm{a}$ & $77.0 \mathrm{~b}$ & $24.5 b$ & $4.4 \mathrm{~b}$ & $3.1 \mathrm{a}$ & $15.4 \mathrm{a}$ \\
\hline & & \multicolumn{8}{|c|}{ Tillage and distance interaction } \\
\hline $\mathrm{CT}$ & 1 & 5.2 & 1.4 & 1.4 & 90.7 & 27.1 & 3.1 & 3.1 & 10.3 \\
\hline $\mathrm{CT}$ & 5 & 4.2 & 1.2 & 1.3 & 76.3 & 23.5 & 3.1 & 1.8 & 13.2 \\
\hline $\mathrm{CT}$ & 10 & 4.9 & 1.3 & 1.4 & 87.8 & 24.7 & 3.1 & 1.4 & 15.2 \\
\hline $\mathrm{CT}$ & 15 & 4.4 & 1.3 & 1.4 & 85.5 & 26.2 & 4.0 & 2.5 & 8.6 \\
\hline $\mathrm{CT}$ & 20 & 4.4 & 1.3 & 1.3 & 80.9 & 25.3 & 5.0 & 3.1 & 13.2 \\
\hline $\mathrm{CT}$ & 25 & 3.8 & 0.9 & 1.6 & 76.3 & 24.8 & 5.1 & 3.0 & 15.3 \\
\hline \multicolumn{2}{|c|}{ Average } & $4.5 \mathrm{X}^{\dagger}$ & $1.2 \mathrm{X}$ & $1.4 \mathrm{Y}$ & 82.X & $25.2 X$ & $3.9 \mathrm{X}$ & $2.4 \mathrm{X}$ & $12.6 \mathrm{X}$ \\
\hline NT & 1 & 4.8 & 1.4 & 1.8 & 64.8 & 25,8 & 4.2 & 2.4 & 9.8 \\
\hline NT & 5 & 5.2 & 1.4 & 1.7 & 69.4 & 26.0 & 4.1 & 2.1 & 9.3 \\
\hline NT & 10 & 4.5 & 1.3 & 0.9 & 53.3 & 28.9 & 3.7 & 2.4 & 9.5 \\
\hline NT & 15 & 3.9 & 1.0 & 1.3 & 46.4 & 20.9 & 3.4 & 1.2 & 11.4 \\
\hline NT & 20 & 4.5 & 1.1 & 1.4 & 95.4 & 27.1 & 5.5 & 2.5 & 11.1 \\
\hline NT & 25 & 3.9 & 1.1 & 2.1 & 71.7 & 25.8 & 3.5 & 3.0 & 14.9 \\
\hline \multicolumn{2}{|c|}{ Average } & $4.5 \mathrm{X}$ & $1.2 \mathrm{X}$ & $1.5 \mathrm{X}$ & $66.8 X$ & $25.7 X$ & $4.0 \mathrm{X}$ & $2.3 \mathrm{X}$ & $11.0 \mathrm{X}$ \\
\hline \multicolumn{2}{|c|}{$\begin{array}{c}\mathrm{LSD}_{\mathrm{P} \leq 0.05} \\
\text { Tillage } \mathrm{x} \text { distance }\end{array}$} & ns & ns & ns & 13.0 & ns & 0.6 & 0.7 & 1.9 \\
\hline
\end{tabular}

$\mathrm{CT}=$ Conventional till, $\mathrm{NT}=$ No-till, $\mathrm{Ca}=$ Calcium, $\mathrm{Mg}=$ Magnesium, $\mathrm{K}=$ Potassium, $\mathrm{Na}=$ Sodium, $\mathrm{Fe}=$ Iron, $\mathrm{Cu}=\mathrm{Copper}$, $\mathrm{Zn}=$ Zinc, and $\mathrm{Mn}=$ Manganese.

$\dagger$ Mean separated by same upper case letter between CT and NT within each column was non-significant at $\mathrm{p} \leq 0.05$ by tillage.

*Mean separated by same lower case letter within each column was non-significant at $p \leq 0.05$ by sampling distance. 


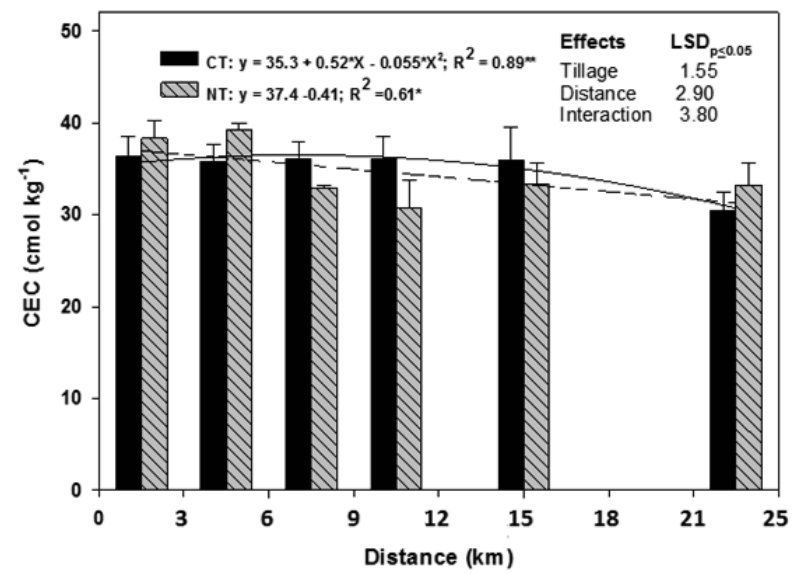

Fig. 1. Effects of cement dust on soil effective cation exchange capacity (CEC) of NT and CT soil at different sampling distances from the cement plant.

The significant tillage $\mathrm{x}$ sampling distance interaction suggests that greater deposition of $\mathrm{CaCO}_{3}^{-}, \mathrm{Ca}-$, or $\mathrm{Mg}$-enriched dust on soil near the cement plant is most probably responsible for higher $\mathrm{TC}$ and $\mathrm{CaCO}_{3}$ contents in NT over CT. Moreover, there were higher TC and TN contents under NT than under CT, which is probably due to greater stabilization of $\mathrm{SOM}$ by $\mathrm{CaCO}_{3}$. Since $\mathrm{C}$ is stoichiometrically linked with $\mathrm{TN}$ in $\operatorname{SOM}[35,36]$, a higher TC content may have invariably increased TN content or vice versa under NT than under CT.

\section{Soil Biological Properties}

Bacterial populations, AlkP, and $\mathrm{DH}$ activity except $\mathrm{BR}$, AcdP, and UA were significantly influenced by tillage and sampling distance without interaction

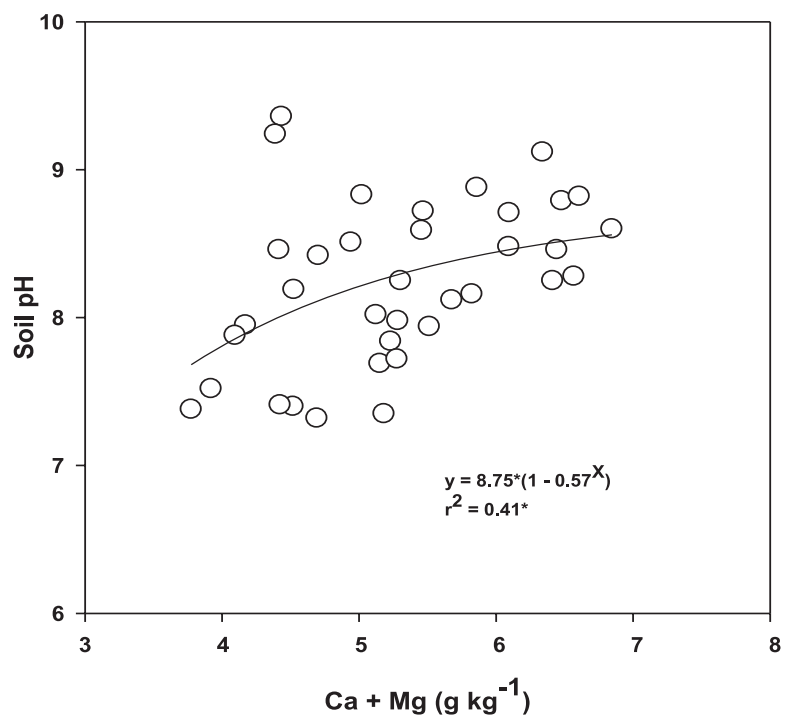

Fig. 2. Effects of cement dust containing $\mathrm{Ca}$ and $\mathrm{Mg}$ on $\mathrm{pH}$ of NT and CT soil at different sampling distances from the cement plant.
(Tables 3 and 4). The numbers of the bacterial population showed a significant linear positive increase with sampling distance in both CT and NT. The rate of increase of bacterial populations was higher under NT $\left(5.1 \times 10^{6} \mathrm{cfu} \mathrm{g}^{-1}\right.$ soil $\left.\mathrm{km}^{-1}\right)$ than under CT $\left(4.2 \times 10^{6} \mathrm{cfu} \mathrm{g}^{-1}\right.$ soil $\left.\mathrm{km}^{-1}\right)$. The numbers of bacterial populations showed irregular changes over $15 \mathrm{~km}$ sampling distance. In contrast, the fungal populations showed a significant quadratic increase with sampling distance regardless of tillage systems. However, the rate of increase of fungal spores was higher under NT $\left(1.1 \times 10^{4}\right.$ spore $\mathrm{g}^{-1}$ soil $\left.\mathrm{km}^{-1}\right)$ than under CT $\left(0.6 \times 10^{4}\right.$ spore $\mathrm{g}^{-1}$ soil km-1 $)$. As expected, the total microbial populations showed a linear positive correlation with sampling distance in both $\mathrm{CT}$ and NT. The rate of increase of total populations was more in NT $\left(5.1 \times 10^{4} \mathrm{cfu} \mathrm{g}^{-1} \mathrm{~s}\right.$ oil km-1) than in CT $\left(3.7 \times 10^{4} \mathrm{cfu} \mathrm{g}^{-1}\right.$ soil km-1). The CT had $17.5 \%$ more bacteria, but $94 \%$ more fungus under NT than under CT. The BR had shown a quadratic decrease with sampling distance regardless of tillage systems. However, the rate of increase of BR with sampling distance was $388 \mathrm{mg} \mathrm{CO}_{2} \mathrm{~kg}^{-1}$ soil km $\mathrm{km}^{-1}$ under $\mathrm{CT}$ and $196 \mathrm{mg} \mathrm{CO}_{2} \mathrm{~kg}^{-1}$ soil km $\mathrm{km}^{-1}$ under NT. The NT had $50 \%$ less BR than CT (Table 3).

The AlkP showed a significant linear decrease with sampling distance in CT and NT (Table 4). The rate of decrease of AlkP was $1.51 \mu \mathrm{g}$ pNP g $\mathrm{g}^{-1}$ soil km $\mathrm{km}^{-1}$ under $\mathrm{CT}$ and $1.11 \mu \mathrm{g} \mathrm{pNP} \mathrm{g}^{-1}$ soil $\mathrm{km}^{-1}$ under NT. AlkP have shown irregular change depending on sampling distance. In contrast, a significant linear increase of DH activity under NT and a quadratic response between DH activity and sampling distance was observed in CT. However, the rate of increase of DH activity was $4.5 \mu \mathrm{g}$ TPF $\mathrm{g}^{-1}$ soil km $\mathrm{km}^{-1}$ under NT and $5.11 \mu \mathrm{g}$ TPF g $\mathrm{g}^{-1}$ soil km $\mathrm{km}^{-1}$ under CT. The AcdP showed a quadratic relationship with sampling distance regardless of tillage systems. UA showed a linear increase with sampling distance regardless of tillage systems. On average, the CT had a 13\% higher AcdP than NT. Likewise, urease activity was more than $12 \%$ higher under CT than under NT.

When plotted, the enzyme activity showed close relationships with soil pH (Fig. 3). The AcdP decreased non-linearly with increasing soil $\mathrm{pH}$ in both $\mathrm{CT}$ and NT. However, the AcdP was affected less by the rise of soil $\mathrm{pH}$ under CT than under NT. In contrast, the AlkP activity increased linearly with the rise of soil $\mathrm{pH}$. UA decreased linearly with the rise of soil $\mathrm{pH}$, and the rate of decrease was more under NT than under CT. DH activity also decreased linearly with increasing soil $\mathrm{pH}$ in both CT and NT, but the rate of decrease was greater under CT than under NT.

Cement dust and other environmental conditions resulting from cement dust pollution affected the microbial population and activities $[1,5,6]$. Soil microbial populations and their activities respond quickly to changes in inputs, management practices, and other external conditions by changing their dominance, activities, or species composition [37]. With decreasing sampling distance from the cement plant, the bacterial 
Table 3. Effects of cement dust on bacterial and fungal populations and basal respiration in NT and CT soil at different sampling distances from the cement plant.

\begin{tabular}{|c|c|c|c|c|c|}
\hline $\begin{array}{l}\text { Tillage } \\
\text { system }\end{array}$ & $\begin{array}{l}\text { Sampling } \\
\text { distance }\end{array}$ & $\begin{array}{c}\text { Bacteria }\left(\times 10^{6}\right) \\
\text { cfu g }^{-1} \text { soil }\end{array}$ & $\begin{array}{l}\text { Fungi }\left(\times 10^{4}\right) \\
\text { spore } \mathrm{g}^{-1} \text { soil }\end{array}$ & Total $\left(\mathrm{x} 10^{6}\right)$ & $\begin{array}{c}\mathrm{BR} \\
\mathrm{mg} \mathrm{CO} \mathrm{kg}^{-1} \mathrm{~d}^{-1}\end{array}$ \\
\hline & 1 & $281.7 d^{*}$ & $36.1 \mathrm{~d}$ & $282.0 \mathrm{~d}$ & $22.8 \mathrm{c}$ \\
\hline & 5 & $300.6 \mathrm{c}$ & $47.1 \mathrm{c}$ & $301.0 \mathrm{c}$ & $25.5 b$ \\
\hline & 10 & $276.1 d$ & $47.0 \mathrm{c}$ & $276.5 \mathrm{~d}$ & 29.1ab \\
\hline & 15 & $352.4 \mathrm{~b}$ & $59.3 \mathrm{a}$ & $352.9 \mathrm{~b}$ & $29.9 \mathrm{ab}$ \\
\hline & 20 & $281.3 \mathrm{~d}$ & $59.3 \mathrm{a}$ & $281.8 \mathrm{~d}$ & $30.7 \mathrm{a}$ \\
\hline & 25 & $390.9 a$ & $52.7 \mathrm{bc}$ & $390.4 \mathrm{a}$ & $29.7 \mathrm{ab}$ \\
\hline & & \multicolumn{4}{|c|}{ Tillage and distance interaction } \\
\hline $\mathrm{CT}$ & 1 & 309.3 & 26.6 & 309.5 & 25.8 \\
\hline $\mathrm{CT}$ & 5 & 328.7 & 31.4 & 329.0 & 29.6 \\
\hline $\mathrm{CT}$ & 10 & 295.5 & 35.8 & 295.8 & 34.5 \\
\hline $\mathrm{CT}$ & 15 & 350.6 & 43.2 & 350.0 & 33.7 \\
\hline $\mathrm{CT}$ & 20 & 308.6 & 43.1 & 309.0 & 35.5 \\
\hline $\mathrm{CT}$ & 25 & 400.2 & 33.0 & 387.5 & 34.3 \\
\hline \multicolumn{2}{|c|}{ Average } & $332.1 X^{\dagger}$ & $35.51 \mathrm{Y}$ & $332.4 \mathrm{X}$ & $32.4 \mathrm{X}$ \\
\hline NT & 1 & 260.0 & 47.3 & 260.4 & 20.9 \\
\hline NT & 5 & 294.5 & 63.7 & 295.1 & 22.2 \\
\hline NT & 10 & 258.7 & 60.2 & 259.2 & 22.6 \\
\hline NT & 15 & 356.2 & 76.4 & 356.9 & 24.2 \\
\hline NT & 20 & 256.0 & 70.5 & 256.7 & 25.8 \\
\hline NT & 25 & 383.6 & 73.4 & 384.0 & 25.1 \\
\hline \multicolumn{2}{|c|}{ Average } & $301.5 \mathrm{Y}$ & $62.2 \mathrm{X}$ & $302.0 \mathrm{Y}$ & $23.3 \mathrm{Y}$ \\
\hline \multicolumn{2}{|c|}{$\begin{array}{c}\mathrm{LSD}_{\mathrm{P} \leq 0.05} \\
\text { Tillage } \mathrm{x} \text { distance }\end{array}$} & ns & ns & ns & ns \\
\hline
\end{tabular}

$\mathrm{CT}=$ Conventional till, NT $=$ No-till, $\mathrm{BR}=$ Basal respiration, and cfu $=$ Colony-forming units.

$†$ Mean separated by same upper case letter between CT and NT within each column was non-significant at $\mathrm{p} \leq 0.05$ by tillage.

*Mean separated by same lower case letter within each column was non-significant at $\mathrm{p} \leq 0.05$ by sampling distance.

and fungal populations and BR significantly decreased and the $\mathrm{CaCO}_{3}, \mathrm{Ca}$, and $\mathrm{Mg}$ contents increased. The adverse effects on microbial populations with decreasing sampling distance may be associated with the rise of soil $\mathrm{pH}$ due to greater accumulation of $\mathrm{CaCO}_{3}-\mathrm{Ca}$-, and $\mathrm{Mg}$-enriched dust emitted from the cement plant. Microbial populations often reduced by high $\mathrm{pH}$ from excess liming or alkaline materials; by heavy metals or other contaminants $[38,39]$. A lower number of microbial populations at sampling sites near the cement plant closely correspond to lower BR. The significant positive correlation of $\mathrm{Ca}$ and $\mathrm{Mg}$ contents with soil $\mathrm{pH}$ explains the adverse effects of cement dust on soil microbial populations, and the fungal populations were more susceptible than the bacterial populations.

Soil $\mathrm{pH}$ influenced AcdP and AlkP, urease, and DH enzyme activities by influencing the concentration of inhibitors or activators in the soil and the effective concentration of the substrate [40]. Acid and alkaline phosphatase activities were closely associated with soil acidity [11]. The functional groups that alter conformational and chemical changes essential for enzymatic catalysis are very sensitive to $\mathrm{pH}$ range [41]. However, AlkP activity turned out to be more resistant at high soil $\mathrm{pH}$ [42]. The inverse relationship of the AcdP, urease and $\mathrm{DH}$ activity with soil $\mathrm{pH}$ suggested that the rate of synthesis and release of the AcdP by soil microbes, or the functional stability of the AcdP affected by rise of $\mathrm{pH}$ [1]. Leviney [43] reported that optimum soil $\mathrm{pH}$ for UA ranged between 7.0. Similarly, the maximum DH activity is reported at soil $\mathrm{pH}$ of 6.6-7.2 [44]. Since both urease and DH activity had been greatly influenced by substrate availability, low amounts of labile organic $\mathrm{C}$ and $\mathrm{N}$ in high $\mathrm{pH}$ soil close to cement plant correspondingly resulted in low levels of urease and DH activity [45]. Likewise, a difference in microbial 
Table 4. Effects of cement dust on AcdP, AlkP, UA, and DH activities in NT and CT soil at different sampling distances from the cement plant.

\begin{tabular}{|c|c|c|c|c|c|}
\hline \multirow{2}{*}{$\begin{array}{l}\text { Tillage } \\
\text { system }\end{array}$} & \multirow{2}{*}{$\begin{array}{l}\text { Sampling } \\
\text { distance }\end{array}$} & AcdP & AlkP & \multirow{2}{*}{$\begin{array}{c}\mathrm{UA} \\
\left(\mathrm{mg} \mathrm{kg}^{-1} 2 \mathrm{~h}^{-1}\right)\end{array}$} & \multirow{2}{*}{$\begin{array}{c}\mathrm{DH} \\
\left(\mathrm{mg} \mathrm{kg}^{-1} \mathrm{~d}^{-1}\right)\end{array}$} \\
\hline & & \multicolumn{2}{|c|}{$\left(\mu \mathrm{g} \mathrm{g}^{-1} \mathrm{~h}^{-1}\right)$} & & \\
\hline & 1 & $31.0 \mathrm{c} *$ & $78.8 \mathrm{a}$ & $17.6 \mathrm{c}$ & $59.5 f$ \\
\hline & 5 & $33.4 b$ & $80.1 \mathrm{a}$ & $21.5 b$ & $78.6 \mathrm{e}$ \\
\hline & 10 & $35.0 \mathrm{~b}$ & $74.7 b$ & $19.1 b c$ & $88.7 \mathrm{~d}$ \\
\hline & 15 & $38.2 \mathrm{a}$ & $66.6 \mathrm{~cd}$ & $21.6 b$ & $106.5 \mathrm{c}$ \\
\hline & 20 & $42.3 \mathrm{a}$ & $69.1 \mathrm{c}$ & $23.5 b$ & $124.6 b$ \\
\hline & 25 & $43.4 \mathrm{a}$ & $58.7 \mathrm{~d}$ & $26.8 \mathrm{a}$ & $169.7 \mathrm{a}$ \\
\hline & & \multicolumn{4}{|c|}{ Tillage and distance interaction } \\
\hline $\mathrm{CT}$ & 1 & 33.0 & 84.6 & 19.2 & 77.2 \\
\hline $\mathrm{CT}$ & 5 & 35.9 & 89.6 & 21.4 & 84.3 \\
\hline $\mathrm{CT}$ & 10 & 36.2 & 80.8 & 20.6 & 119.2 \\
\hline $\mathrm{CT}$ & 15 & 39.4 & 65.8 & 21.4 & 139.1 \\
\hline $\mathrm{CT}$ & 20 & 43.4 & 80.2 & 22.4 & 146.0 \\
\hline $\mathrm{CT}$ & 25 & 42.0 & 65.4 & 25.1 & 159.0 \\
\hline \multicolumn{2}{|c|}{ Average } & $38,3 \mathrm{X} \dagger$ & $77.7 X$ & $21,6 \mathrm{X}$ & $126,3 X$ \\
\hline NT & 1 & 28.0 & 73.1 & 14.2 & 45.9 \\
\hline NT & 5 & 29.9 & 70.6 & 19.6 & 69.9 \\
\hline NT & 10 & 33.9 & 62.6 & 17.8 & 53.3 \\
\hline NT & 15 & 36.8 & 60.2 & 18.5 & 78.3 \\
\hline NT & 20 & 39.2 & 54.7 & 21.1 & 76.0 \\
\hline NT & 25 & 40.3 & 55.3 & 23.3 & 118.6 \\
\hline \multicolumn{2}{|c|}{ Average } & $34,6 \mathrm{Y}$ & $62.4 \mathrm{Y}$ & $19.1 \mathrm{Y}$ & $70.9 \mathrm{Y}$ \\
\hline \multicolumn{2}{|c|}{$\begin{array}{c}\mathrm{LSD}_{\mathrm{P} \leq 0.05} \\
\text { Tillage } \mathrm{x} \text { distance }\end{array}$} & & ns & ns & ns \\
\hline
\end{tabular}

$\mathrm{CT}=$ Conventional till, $\mathrm{NT}=$ No-till, $\mathrm{AcdP}=$ Acid phosphatase, $\mathrm{AlkP}=$ Alkaline phosphatase, $\mathrm{UA}=$ Urease, $\mathrm{DH}=$ Dehydrogenase, $\dagger$ Mean separated by same upper case letter between CT and NT within each column was non-significant at $\mathrm{p} \leq 0.05$ by tillage.

*Mean separated by same lower case letter within each column was non-significant at $\mathrm{p} \leq 0.05$ by sampling distance.

populations may be reflected in the differences of soil enzyme activities [40]. Higher enzyme activity under $\mathrm{CT}$ as compared with NT is possibly due to a greater survival strategy of microbes from disturbance stress by frequent plowing [46].
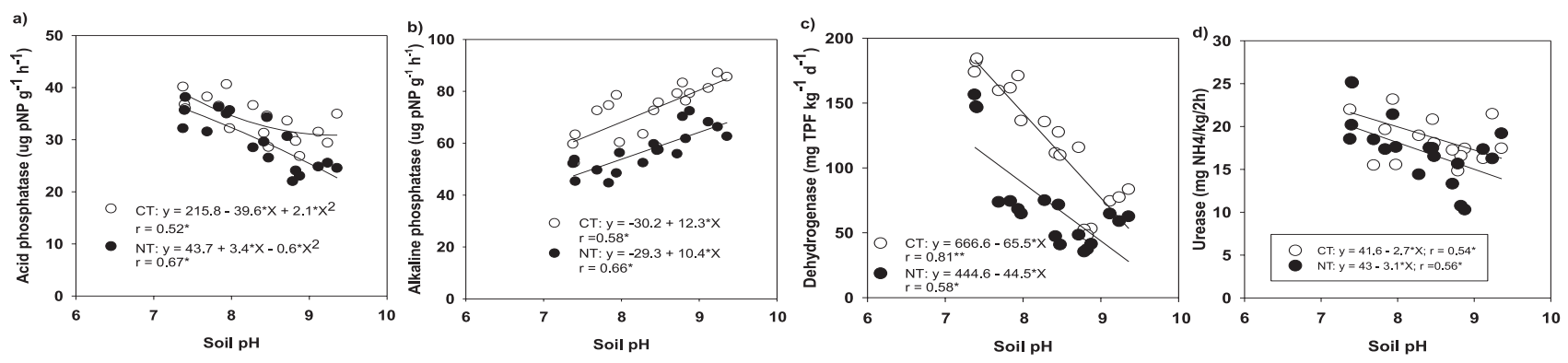

Fig. 3. Effects of soil pH on AcdP and AlkP, UA and DH activity in NT and CT soil at different sampling distances from the cement plant.
A significantly higher bacterial population and BR with less fungal populations under CT are due to greater physical disturbances from annual plowing and less availability of $\mathrm{C}$ and nutrients than under NT. Frequent plowing fragments and crop residues mix increased 

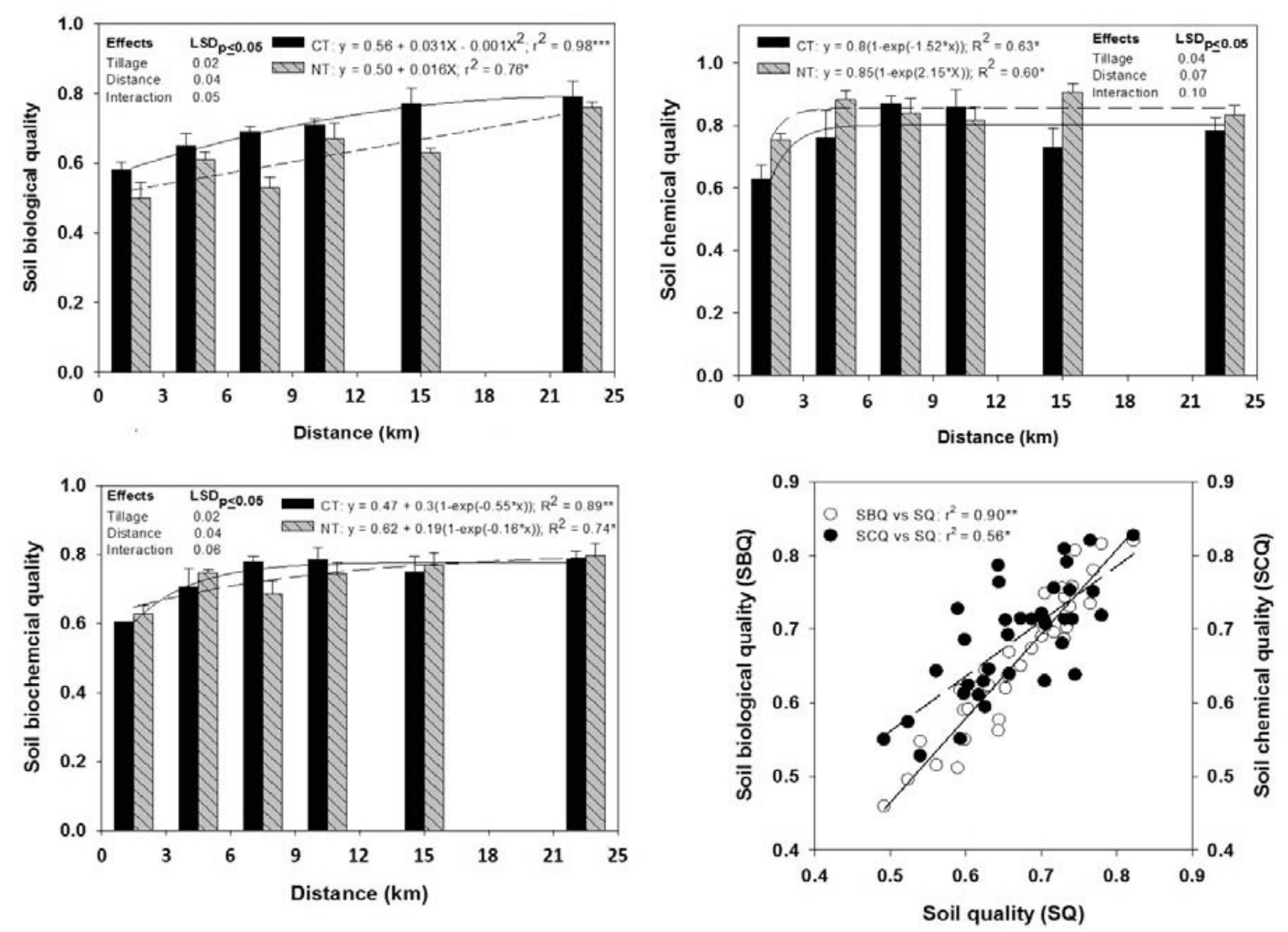

Fig. 4. Effects of cement dust on biological, chemical, and soil quality in NT and CT soil at different sampling distances from the cement plant.

soil aeration and temperature, degrade soil structures and expose protected $\mathrm{C}$ to microbes, and subsequently cause an increase in release of $\mathrm{CO}_{2}$ from accelerated decomposition and chemical oxidation of $\mathrm{C}$ [18]. CT also affects soil biology by fragmenting roots, fungal hyphae, and mycorrhizal associations [47]. An intense competition among the heterotrophic microbes for the labile $\mathrm{C}$ under $\mathrm{CT}$ is expected to favor a predominance of bacteria because of their adaptability, generalist feeding habit, short generation time, smaller size, and rapid dispersal [48]. Fungi have greater $\mathrm{C}$ assimilation efficiency than bacteria, and so they release less $\mathrm{CO}_{2}$ as BR [18].

\section{Soil Quality}

SQ indices calculated based on biological and chemical properties were influenced significantly by tillage, sampling distance, and tillage $\mathrm{x}$ sampling distance interaction (Fig. 4). SBQ was $12 \%$ higher in CT than in NT (Fig. 4a). In contrast, SCQ was 9\% lower in CT than NT (Fig. 4b). The overall SQ did not vary significantly between CT and NT (Fig. 4c). The SBQ showed a linear positive correlation with sampling distance in NT and quadratic relation in $\mathrm{CT}$. The rate of change of SBQ was higher in CT (0.014 per $\mathrm{km})$ than in NT (0.009 per km) with sampling distance (Fig. 4a). The SCQ responded non-linearly with sampling distance in both $\mathrm{CT}$ and NT, and the rate of change of SCQ was smaller in CT (0.9 per $\mathrm{km})$ than in NT (1.2 per km) (Fig. 4b). Like SCQ, the SQ had a nonlinear relationship with sampling distance. The rate of change of SQ was higher in CT $(0.33$ per $\mathrm{km})$ than in NT (0.09 per km) over the sampling distance (Fig. 4c). When plotted, the SBQ significantly accounted for $90 \%$ of the linear variability in the SQ (Fig. 4d). In contrast, the SCQ accounted for only $56 \%$ of the linear variability in the SQ. Greater accountability of the variations in the SQ by the SBQ over SCQ suggested that the SBQ is a more sensitive indicator for early detection of SQ changes in response to environment stress or management practices.

\section{Conclusion}

The bacterial and fungal populations, BR, AcdP, urease, and $\mathrm{DH}$ activity except AlkP have shown a positive correlation with sampling distance from the cement plant. Alkaline dust emitted from the cement plant is closely associated with the rise of soil $\mathrm{pH}$ and consequently affected microbial populations, BR, and 
enzyme activities in both CT and NT. The adverse effects with decreasing sampling distance may be associated with the rise of soil $\mathrm{pH}$ due to greater accumulation of $\mathrm{CaCO}_{3}-\mathrm{Ca}$-, and $\mathrm{Mg}$-enriched dust emitted from the cement plant. Higher bacterial populations, BR, and enzyme activity but lower fungal populations under CT are due to greater physical disturbance than NT. Moreover, a greater survival strategy of microbes from disturbance stress was exerted by frequent plowing. SQ has been affected negatively by depending on the distance of cement dust pollution in both CT and NT. These characteristics affected more in NT than CT and the close proximity of the cement plant.

\section{Acknowledgements}

Serdar Bilen wrote the paper, performed the experiments, analyzed the data and coordinated the data collection. Murat Bilen supported Serdar Bilen in analysis and data collection, writing and proofreading the paper. Veysel Turan supported Serdar Bilen in performing the experiments, data collection and laboratory analysis.

\section{Conflict of Interest}

The authors declare no conflict of interest.

\section{References}

1. BILEN S. Effect of cement dust pollution on microbial properties and enzyme activities in cultivated and no-till soils. African Journal of Microbiology Research, 4, 2418, 2010.

2. AISWARYA R., WILLIAM A.A. Air Quality Impacts of Petroleum Refining and Petrochemical Industries. Environments, 4 (3), 66, 2017.

3. ABRIL G.A., WANNAZ E.D., MATEOS A.C., PIGNATA M.L. Biomonitoring of airborne particulate matter emitted from a cement plant and comparison with dispersion modeling results. Atmospheric Environment, 82, 154, 2014.

4. ADDO M.A., DARKO E.O., GORDON C., NYARKO B.J.B. Contamination of soils and loss of productivity of cowpea (Vigna unguiculata) caused by cement dust pollution. International Journal of Research in Chemistry and Environment, 3 (1), 272, 2013.

5. ARUL A., NELSON R. Effect of Cement Dust Pollution on Morphology and Photosynthetic Pigments of Some Legume Plants Grown in Ariyalur District, Tamil $\mathrm{Nadu}$. International Journal of Advanced Multidisciplinary Research, 2 (12), 59, 2015.

6. ISRAEL O., TAJUDEEN Y., UMAR I. Bacteriological Assessment of Soil Contaminated with Cement Dust. Frontiers in Environmental Microbiology, 2 (3), 12, 2016.

7. ANONYMOUS. Soil respiration. Soil Health - Guides for Educators. The United States Department of Agriculture
(USDA) and Natural Resources Conservation Service (NRCS), 2014.

8. MARGESIN R., MINERBI S., SCHINNER F. Long-Term Monitoring of Soil Microbiological Activities in Two Forest Sites in South Tyrol in the Italian Alps. Microbes and Environments, 29 (3), 277, 2014.

9. MLITAN A.B., ALRAYES H.M., ALREMALLY A.M., ALMEDAHAM A.M., OAEN S. O., ALDERWISH M.N. Toxicity of heavy metals and microbial analysis of soul samples collected from the area around Zliten cement Factory. Open Journal of Air Pollution, 2, 2, 2013.

10. WOLIŃSKA A., STĘPNIEWSKA Z. Microorganisms Abundance and Dehydrogenase Activity As a Consequence of Soil Reoxidation Process, In: Soil Tillage \& Microbial Activities, M. Miransari, (Ed.), Research Singpost, Kerala, India. 111, 2011.

11. KALEMBASA S., SYMANOWICZ B. Enzymatic Activity of Soil after Applying Various Waste Organic Materials, Ash, and Mineral Fertilizers. Polish Journal of Environmental Studies. 21 (6), 1635, 2012.

12. DHAL B., THATOL H.N., DAS N.N., PANDEY B.D. Chemical and microbial remediation of hexavalent chromium from contaminated soil and mining/ metallurgical solid waste: a review. The Journal of Hazardous Materials, 250, 272, 2013.

13. BAKER L.R., WHITE P.M., PIERZYNSKI G.M. Changes in microbial properties after manure, lime, and bentonite application to a heavy metal-contaminated mine waste. Applied Soil Ecology, 48, 1, 2011.

14. VARGAS R.S., BATAIOLLI R., DA COSTA P.B., LISBOA B., PASSAGLIA L.M.P., BENEDUZI A., VARGAS L.K. Microbial quality of soil from the Pampa biome in response to different grazing pressures, Genetics and Molecular Biology, 38 (2), 205, 2015.

15. GARCIA-ORENES F., MORUGAN-CORONADO A., ZORNOZA R., CERDA A., SCOW K. Correction: Changes in Soil Microbial Community Structure. In: fluenced by Agricultural Management Practices in a Mediterranean Agro-Ecosystem, PLoS One, www.plosone. org, 8 (11), e0152958, 2016.

16. BACMAGA M., KUCHARSKI J., WYSZKOWSKA J. Microbial and enzymatic activity of soil contaminated with azoxystrobin. Environmental Monitoring and Assessment. 187 (10), 1, 2015.

17. REJI P.M., YUCHENG F., LEONARD G., RAMBLE A., KIPLING S.B. Impact of No-Tillage and Conventional Tillage Systems on Soil Microbial Communities. Applied and Environmental Soil Science. June 2012.

18. ISLAM K.R., WEIL R.R. Land use effects on soil quality in a tropical forest ecosystem of Bangladesh. Agriculture, Ecosystems and Environment, 79, 9, 2000.

19. SOIL SURVEY STAFF. Soil Survey Staff (2014) Keys to Soil Taxonomy. 12 ${ }^{\text {th }}$ Edition, USDA-Natural Resources Conservation Service, Washington DC, 2014.

20. NANDHINI B., JOSEPHINE R.M. A study on bacterial and fungal diversity in potted soil. International Journal of Current Microbiology and Applied Sciences. 2 (2), 1, 2013.

21. MAITI S.K. Soil Microbiological Parameters. Chapter 21. In: Ecorestoration of the Coalmine Degraded Lands, \#Springer, New Delhi India, 319, 2013.

22. TABATABAI M.A. Soil enzymes. In: Weaver RW, Angle JS, Bottomley PS (eds) Methods of soil analysis: microbiological and biochemical properties. Part 2. SSSA Book Ser. 5, SSSA, Madison, WI, 775, 1994. 
23. NELSON D.W., SOMMERS L.E. Total carbon, organic carbon, and organic matter. In: Bartels JM, Bigham JM (eds) Methods of soil analysis, Part 3-Chemical Methods. ASA-SSSA, Madison, WI, 961, 1996.

24. LEOPPERT R.H., SUAREZ D.L. Carbonate and gypsum. In: Bartels JM., Bigham JM. (eds) Methods of soil analysis, Part 3, ASA-SSSA, Madison, WI, 437, 1996.

25. HANDERSHOT W.H., LALANDE H., DUQUETTE M. Soil Reaction and Exchangeable Acidity. In: Martin RC. (ed) Soil sampling and methods of analysis, Canadian Society of Soil Science, Lewis Publishers, Boca Raton, FL, 141, 1993.

26. HANLON E.A., DE VORE J.M. IFAS extension soil testing laboratory chemical procedures and training manual. In: FL Cooperation Extension Service Circular 812, Institute of Food and Agriculture Sciences, University of FL, Gainesville, 1989.

27. KNUDSEN D., BEEGLE D. Recommended phosphorous tests. In: Dahnke WC. (ed) Recommended chemical soil test procedures for the north central region, North Central Region Publication No: 221, North Dakota, USA, $12,1988$.

28. LINDSAY W.L., NORVELL W.A. Development of a DTPA test for zinc, iron, manganese, and copper. Soil Science Society of America Journal, 42, 421, 1978.

29. GEE G.W., BAUDER J.W. Particle-size analysis. In: Klute A (ed) Methods of soil analysis. Part 1, $2^{\text {nd }}$ ed.; Agron Monogr 9, ASA and SSSA, Madison, WI, 383, 1986.

30. SAS INSTITUTE. The SAS system for Microsoft Windows for x64. SAS Institute Inc., SAS Campus Drive, Cary, North Carolina 27513. September 2017.

31. LIU X., HERBERT S.J., HASHEMI A.M., ZHANGL X., DING G. Effects of agricultural management on soil organic matter and carbon transformation - a review. Plant Soil Environment, 52 (12), 531, 2006.

32. KHAMPARIA A., CHATTERGEE S.K., SHARMA G.D. Assessment on effect of cement dust pollution on soil health. Journal of Environmental Research and Development, 7, 1A, 2012.

33. SINGH A., AGRAWAL M., MARSHALL F.M. The role of organic vs. inorganic fertilizers in reducing phytoavailability of heavy metals in a wastewater-irrigated area. Ecological Engineering, 36, 1733, 2010.

34. ARIMANWA M.C., ONWUKA D.O. ARIMANWA J.I. Effect of Chemical Composition of Ordinary Portland cement on the Compressive Strength of Concrete. International Refereed Journal of Engineering and Science (IRJES). 5, 3, 20, 2016.

35. YANG Y.H., FANG J.Y, GUO D.L, JI C.J., MA W.H. Vertical patterns of soil carbon, nitrogen and carbon: nitrogen stoichiometry in Tibetan grasslands. Biogeosciences Discuss, 7, 1, 2010.

36. MOMEN B., ISLAM K.R., ROWLAND R. Temporal Effects of Elevated Carbon Dioxide and Ozone on Soil Carbon and Nitrogen Stoichiometry in a No-till Soybean-
Wheat Agro-ecosystem. JSM Environmental Science \& Ecology, 1 (2), 1008, 2013.

37. GHOLAMREZA H., KHOSRO M., YOUSEF S. Responses of Soil Microbial Biomass and Enzyme Activities to Tillage and Fertilization Systems in Soybean (Glycine max L.) Production. Frontiers in Plant Science, 7, 1730, 2016.

38. FRIEDLOVÁ M. The influence of heavy metals on soil biological and chemical properties. Soil and Water Research, 5 (1), 21, 2010.

39. YARGHOLI B., S. AZARNESHAN S. Long-term effects of pesticides and chemical fertilizers usage on some soil properties and accumulation of heavy metals in the soil (Case study of Moghan plain's (Iran) irrigation and drainage network). International Journal of Agriculture and Crop Sciences, 7, 518, 2014.

40. FREDERIC O.O., IROHA A.E., OSWALD E.C., Evaluation of the Concentration of selected heavy metals and the effects on soil enzymatic activities in an Abandoned Cement Factory Nigercem Nkalagu and its environs. International Journal of Biochemistry Research \& Review. 4 (1), 16, 2014.

41. DICK W.A., CHENG L., WANG P. Soil acid and alkaline phosphatase activity as $\mathrm{pH}$ adjustment indicators. Soil Biology and Biochemistry, 32, 1915, 2000.

42. TURNER B.L. 2010. Variation in $\mathrm{pH}$ optima of hydrolytic enzyme activities in tropical rain forest soils. Applied and Environmental Microbiology, 76 (19), 6485, 2010.

43. DEVINEY A.V. Effects of $\mathrm{pH}$ on Urease Activity in Swine Urine and Urea Solution. North Carolina State University Biological and Agricultural Engineering Department, xExtension.org, http://articles.extension.org/pages/74249/ effects-of-ph-on-urease-activity-in-swine-urine-and-ureasolution, 2018.

44. NATYWA M., SELWET M. Respiratory and Dehydrogenase Activities In The Soils Under Maize Growth In The Conditions of Irrigated and Nonirrigated Fields. Acta Scientiarum Polonorum. Agricultura, 10, 93, 2011.

45. LIU X., GUO K., HUANG L., JI Z., JIANG H., LI H., JIANFENG Z. Responses of absolute and specific enzyme activity to consecutive application of composted sewage sludge in a Fluventic Ustochrept. PLoS One, www.plosone. org, 12 (5), e0177796, 2017.

46. ACOSTA-MARTINEZ V., ZOBECK T.M., ALLEN V. Soil microbial, chemical and physical properties in continuous cotton and integrated crop-livestock systems. Soil Science Society of America Journal, 68, 1875, 2004.

47. BRITO I., GOSS M.J., DE CARVALHO M. Effect of tillage and crop on arbuscular mycorrhiza colonization of winter wheat and triticale under Mediterranean conditions. Soil Use Management, 28, 202, 2012.

48. ISLAM K.R., MULCHI C.L., ALI A.A. Interactions of tropospheric $\mathrm{CO}_{2}$ or $\mathrm{O}_{3}$ enrichments and moisture variations on microbial biomass and respiration in soil. Global Change Biology, 6, 255, 2000. 